standard of living they might enjoy if they were based, say, at the Battelle Institute in Frankfurt.

ERII will start formally on 1 June, when two members of the Georgia Institute of Technology Engineering Experiment Station begin work in Limerick. Initially they will be housed in Ireland's National Institute for Higher Education, where president Dr Edward Walsh is said to be playing an "aggressive" part in forging links between university and industry. Recruitment is under way for eight engineers, scientists and computer specialists, but in three years' time, when ERII will move to its own buildings, it is planned that staffing levels should increase to 80 .

To finance ERII, the Industrial Development Authority is paying for the buildings (I£1.5 million); and the balance will come from such sponsors as Guinness Ireland, the Bank of Ireland, Allied Irish Banks and the industrial Rohan Group. Nevertheless the authority is seeking another I $£ 500,000$ to launch the institute "effectively", and would like more companies to contribute to the consortium.

Robert Walgate

\section{UK universities}

\section{Jobs to be cut?}

One week after the British government's budget, the University Grants Committee has plucked up courage to make some guesses on the quantitative implications for universities. Dr Edward Parkes, the chairman, told the Public Accounts Committee of the House of Commons last week that to meet an 11 per cent cut in real terms in the universities' grant over the next three years, 3,000 academics and 4,000 other staff would have to lose their jobs. Redundancy payments to academics, said Dr Parkes, could be somewhere between $£ 40,000$ and $£ 80,000$, although realistic figures would not be known until cases had been through the courts. The total cost to the universities could be $£ 100-200$ million.

Dr Parkes has since said that in addition to 3,000 redundancies, 2,000 jobs would have to be lost through natural wastage. $\mathrm{He}$ estimates that 3,000 academics will leave their posts in the next three years, either through retirement or to take posts else-

\title{
Bulgarian astronomers look up and abroad
}

Bulgaria's new National Astronomical Observatory on Mount Rozhen, opened on 13 March 1981 by President Todor Zhivkov, was several times referred to in the inaugural speeches as a "pre-Congress gift to Bulgarian science"'. The term is appropriate, for the theses for the forthcoming Congress of the Bulgarian Communist Party state that in the new Five-Year Plan "primary importance should be paid to fundamental research".

This is in sharp contrast to the policies of many other East European countries, which tend to give first priority to application. According to Kiril Serafimov, head of the Bulgarian Committee for Space Research and Exploitation, "we are also a European country and understand that without fundamental science nothing is possible".

Speaking at the opening ceremony, Dr Serafimov inevitably referred to Bulgaria's "thousand-year-old" interest in astronomy - the country is this year celebrating its 1,300 th anniversary of statehood. The observatory has three telescopes and a large data-processing and computer unit. The main telescope has a $200-\mathrm{cm}$ hyperbolic mirror with a Coude-RicheyCretien focusing system and will be used primarily for work on binaries and variable stars. The second, a 70-cm Schmidt instrument (effective diameter $50 \mathrm{~cm}$ ) with a $4^{\circ} \mathrm{x}$ $4^{\circ}$ field of view, will be used for preliminary search and scanning work. The smallest, a $60-\mathrm{cm}$ instrument, is especially adapted for photoelectric work and brightness determinations.

The observatory is the most southerly in the socialist bloc (and, according to Bulgarian claims, the second largest optical observatory in Europe). The Rozhen team expects to cooperate closely with the Soviet observatories, especially the Crimean Astrophysical Laboratory and the Special Astrophysical Observatory in the Caucasus, on approximately the same latitude. Intra-Comecon cooperation is well represented at Rozhen - the research programme has been worked out in collaboration with teams from the Soviet Union, the German Democratic Republic and Poland. (The optical equipment has been supplied by Carl Zeiss (Jena).) There has also been some French participation in drawing up the programme, while the dataprocessing equipment is largely of Western origin.

Vera Rich

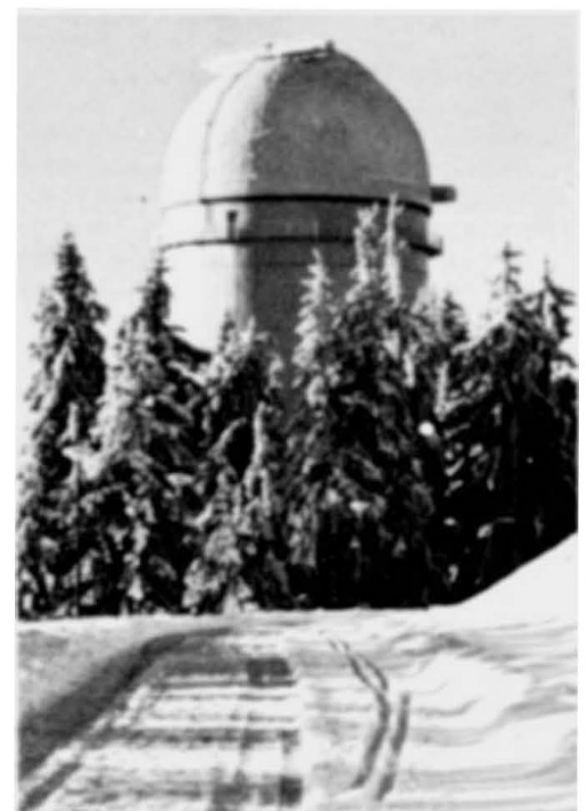

Mount Rozhen in snow where. His current plan allows for 1,000 vital posts to be refilled. A total loss of about 5,000 academic jobs represents just under 15 per cent of the academic workforce. The percentage of job losses will have to be greater than the percentage cut in the budget because economies in other areas of expenditure are virtually impossible, according to Dr Parkes.

The Association of University Teachers disagrees with that view. It is preparing a scheme to avoid large numbers of redundancies by relying on natural wastage, an early retirement option at 50 and spending one-third of the equipment grant on staff. But the scheme is unlikely to appeal to the grants committee which holds that freezing all posts would be the worst option. The problem is that those departments with the highest rate of turnover of staff medicine, science and engineering would suffer most, and in many cases, those are the very departments that the government would like to see least damaged. The committee prefers to maintain minimum flexibility in making new appointments and create the minimum number of redundancies.

The Science Research Council, which provides research grants to individual academics, is particularly concerned that good research should not disappear. Ever optimistic, it says that it may be able to support a few outstanding individuals who would otherwise have to go. Such support, however, is unlikely to be very significant.

The Committee of Vice-Chancellors and Principals has estimated that the grant for 1983-84 will be $£ 80$ million less than that for this year and that the loss from overseas students' fees could remove a further $£ 70$ million, a total sum short of conservative estimates of redundancy payments. The estimated costs may well have come as a surprise to the government, which is showing signs of reconsidering its plans. Sir James Hamilton, Permanent Secretary at the Department of Education and Science, told the Public Accounts Committee that his department was still attempting to work out with the University Grants Committee how the economies could be achieved. Although the budgets for 1981-82 and 1982-83 are fixed, he said, the figure quoted for 1983-84 is still only an estimate, suggesting that there may be room for further negotiation.

Universities, however, are unlikely to make up lost income by taking in more students. Contrary to the impression given in the white paper on public expenditure and by $\mathrm{Mr}$ Mark Carlisle, Secretary of State for Education, Sir James Hamilton told the Public Accounts Committee that the government will not increase the grant to universities that overstep their quota of students. The plan is that student numbers should remain roughly constant, implying greater competition for places as the number of eighteen-year-olds in the population continues to increase over the next few years.

Judy Redfearn 